\title{
Challenging Autonomous Models of Literacy: Street's Call to Action
}

\author{
JOANNE LARSON \\ University of Rochester
}

\begin{abstract}
This article reviews Brian Street's (1995) book Social Literacies: Critical Approaches to Literacy Development, Ethnography, and Education in light of current debates in literacy and education. This essay review will discuss Street's analysis of current issues in the field of literacy with specific focus on his definitions of autonomous and ideological models of literacy and how the shift from autonomous to ideological models will transform literacy practices. The review concludes with a chailenge to researchers to think specifically about how Street's work might impact their own research.
\end{abstract}

The current political atmosphere surrounding literacy education in the United States is pitting Whole Language and Phonics instruction against each other in the struggle for power over the educational agenda. Whole Language teachers, already besieged by district administrators clamoring for evidence of rising standardized test scores, are coming under increasing pressure to abandon meaning-based language arts curricula in favor of decontextualized skills instruction. This dominant literacy pedagogy relies almost exclusively on traditional definitions of literacy as a reified set of basic skills devoid of social context or political implications. Even more socially oriented literacy pedagogues put forward in the Whole Language (Goodman, 1986, 1996; Edelsky, 1991) and Writing Process (Emig, 1971; Graves, 1983, 1994; Perl, 1979) movements are instantiated in classrooms in traditional forms that isolate basic skills (Applebee, 1984; Langer \& Applebee, 1987; Gutierrez, 1992). As can be seen in recent media coverage, African-American and Latino students are once again targeted as in need of basic skills education in order to keep up with the rest of "us." The current conservative political agenda promoting "back-to-basics" is putting increasing pressure on schools to improve standardized test scores, specifically using African-American and Latino students as a target audience, through phonics-based reading programs.

If we, as researchers, are to offer teachers real solutions as they struggle against a strong conservative backlash to create meaningful learning experiences for their

Direct all correspondence to: Joanne Larson, University of Rochester, Wamer Graduate School of Education and Human Development, 1-160E Dewey Hall, Rochester, NY 14627

<joln@troi.cc.rochester.edu>. 
students, then we must challenge the current dichotomous argument between Whole Language and Phonics as a false debate and the wrong question (Coles, in press). We need to ethnographically document, instead, what teachers are doing in their classrooms. If they are not teaching whole language or phonics, then what are they teaching? It is, I suspect, more than a hybrid between whole language and phonics. I suspect that we will find literacy as situated social practice, in practice. Our challenge, then, is to bring evidence of current classroom practice to bear on the public debate in order to move the discussion forward to the more critical agenda set forward by Brian Street (1995) in Social literacies: Critical approaches to iteracy in development, ethnography, and education.

Street's book offers a comprehensive analysis of current social and political issues in literacy education that challenges researchers and educators to rethink their fundamental assumptions underlying definitions of literacy. Given the New Right's pressure to abandon meaning-based pedagogy in favor of a skills-based approach, this book is more than a timely theoretical discussion; it provides, instead, a call for the transformation of literacy practices and a presentation of a critical agenda for what Street terms the "new literacy studies," In this essay review, I will discuss Street's analysis of current issues in the field of literacy with specific focus on his definitions of autonomous and ideological models of literacy and how the shift from autonomous to ideological models will transform literacy practices. I will conclude with a challenge to researchers to think specifically about how Street's work might impact our own research.

\section{Autonomous and Ideological Models of Literacy}

In building his case for the new literacy studies, Street defines autonomous and ideological models of literacy as oppositional theoretical positions. According to Street, autonomous models of literacy are based on essay-text forms of literacy rooted in Western academic circles and represents a culturally specific model that is masked in claims of universalism. In this autonomous model, school-based concepts of literacy are held as a standard definition of literate competence across contexts. Street argues that universalistic conceptions of literacy put forward in autonomous models do not "lift those who learn it out of their socially embedded context" (p. 79) but rather can suppress students under the ideology and social control of the teacher's class. By positioning students as subjugated learners, critical analysis of their social and political context is prevented. Thus, if literacy is represented as a context-neutral skill, then it fulflls the political purposes of those in power to maintain a position of superiority by marginalizing other forms of literate knowledge.

This position is outlined most clearly in chapter five, "The Schooling of Literacy," written with J. Street. This chapter examines how one form of literacy, defined by a conservative middle class discourse of power and knowledge, has come to dominate literacy practices in contemporary schooling. The authors argue 
that through the "pedagogization of literacy" (p. 106), objectified conceptions of literacy are naturalized in practice. Pedagogization is defined as the socially constructed link between institutionalized processes of teaching and learning and literacy. By reducing literacy to a "neutral" set of reading and writing skills, literacy is defined apart from social context and becomes, then, a "content to be taught through authority structures whereby pupils learned the proper roles and identities they were to carry into the wider world" (p. 118). This is a particularly relevant definition of literacy in today's conservative political climate in the U.S. As mentioned, African-American and Latino students, currently labeled as "at risk" or "inner city," are particularly targeted for these skills-oriented pedagogues held as exemplary practices by "back-to-basics" advocates.

Street challenges researchers to investigate "how the assertion of authority and the allocation of participants to specific roles and relationships are inscribed within particular literacy events" (p. 123). Street clains that ethnography will describe these processes most effectively and calls for ethnographies of literacy that will fulfill the need for an ethnographically based conception of literacy as the social practice of reading and writing grounded in social, political, and economic contexts. According to Street, literacy is ideological and situated within the larger ideology of language as social practice. In Street's ideological model, literacy is conceptualized as a critical social practice that makes explicit underlying assumptions and power relations inherent in conceptions of literacy as social process. In other words, literacy is more than acquiring content but, in addition, locates reading and writing in the social and linguistic practices that give them meaning. Thus, cognitive processes of reading and writing are not ignored but are "encapsulated within cultural wholes and within structures of power" (p. 161). An explicitly ideological model of literacy emphasizes the value of ethnography to describe the lives of the people "on the ground" and the ways in which macro social and political processes are enacted in people's daily lives. Furthermore, Street argues that notions of the "great divide" between literacy and orality tend to deflect attention from real meanings and purposes of literacy in the face-to-face lives of local peoples made evident through ethnography. Through ethnography, then, the microgenetic levels of literacy are made visible (Green \& Dixon, 1996).

\section{The Value of Ethnography in the New Literacy Studies}

Literacy research in school contexts is necessary not only to reveal persistent negative consequences on students, but also to highlight successful transformations of the context for literacy learning in effective classrooms. Street appears to argue that because schools perpetuate autonomous models of literacy, researchers should not include them in ethnographic studies of literacy practices or count on schools as possible avenues of change. Understanding the pedagogization of literacy and the consequences of this reification is essential in the construction of a critical redefinition of literacy, however, I would argue that it is equally important not to 
abandon schools as sites for the critical transformation of literacy practices from strictly autonomous models to more situated ideological models. Ethnographic research in schools, 'for example, has documented contexts within which literacy learning is revealed to be a profoundly social process grounded in context (Gutierrez, Larson, Rymes \& Stone, 1995; Duranti \& Ochs, 1986; Larson, 1995a; Rymes, 1995). Furthermore, classroom ethnographies of literacy have documented the consequences of autonomous models of literacy on linguistically and culturally diverse student populations (Gutierrez, 1992, 1993; Gutierrez \& Larson, 1994; Gutierrez, Rymes \& Larson, 1995) and pushed our understanding of the relationship of the community to literacy learning across contexts (Duranti \& Ochs, 1986; Duranti, Ochs \& Ta'ase, in press; Heath, 1983).

In my own work, I have examined how the participation framework can be used as a means of transforming the nature of participation in school-based literacy activities thereby undermining traditional power relations between teacher and student (Larson, 1996). I have argued, for example, that the participation framework that evolves in particular classroom literacy events may represent a common understanding of the available participant roles and the rules of participation constructed in context. The participation framework evolves as a broad social and conceptual framework that represents a choice of footings (Goffman, 1981) available for students to participate in the activity or to interpret meaning. The participation framework becomes a "field of reference maximally accessible to all participants" (Hanks, 1990, p. 49). Bourdieu (1983) describes a field as a space of positions and position taking that presents itself to each participant as a range of possibilities, or a "space of possibles" (p. 344). The participation framework in literacy activity, therefore, can represent the range of roles available for students to assume in literacy events. This sociocultural field regulates students' access to participation by determining the principles of legitimization according to which given forms of engagements are acceptable (Garfinkel, 1972).

Meaning, then, is constructed in interaction as individual text becomes a group construction (Larson, 1995b). A reconceptualization of classroom language and literacy practices that accounts for the profoundly social process of learning inherent in ideological models of literacy can be accomplished in classrooms through the construction of a more symmetrical participation framework within which the meaning of texts can be socially negotiated (Larson, in press). This intersubjective instructional space creates a common understanding of the meanings, limitation, and potential of literacy knowledge and suggests a reconstruction of literacy curricula to account for the ways in which interaction constructs the context for learning (Duranti \& Goodwin, 1992; Nystrand, 1989). In this model, the role of the teacher is transformed from a Foucauldian panoptical observer (Foucault, 1977) seen in most classrooms to that of joint participant in the social construction of literacy knowledge. Thus, all the participants in particular literacy events are both literal and figurative co-authors (Duranti, 1986). Viewing class- 
rooms from the ideological position suggested by Street can, therefore, assist educators in the necessary transformation of school-based literacy practices.

\section{Challenging Research Ideologies}

Disrupting the current hegemonic discourse patterns of traditional literacy instruction requires an examination of how social definitions of appropriate participation internalized in school provide the constitutive rules for interaction in society. By changing these interaction patterns educators can change the nature of knowledge construction in classrooms from autonomous models still dominant today, though masked in the guise of process pedagogues, to socially mediated knowledge construction. These patterns of participation control meaning, i.e., how meaning is constructed in schools, by whom, and for what. If the process of socialization into language and interactional practices of the larger society begins, not only in the family (Schieffelin \& Ochs, 1986; Ochs, 1988, 1992; Ochs \& Taylor, 1992; Ochs, Taylor, Rudolph \& Smith, 1992) or the community (Goodwin, 1990; Heath, 1983; Rogoff, 1990), but in the first years of schooling as children are socialized into the academic discourse community, then reconceptualizing patterns of participation can alter the regularities of interaction in schools and facilitate access to the social construction of literacy knowledge. As Luke (1994) has pointed out, classroom interaction carries powerful messages about what counts as literacy and about the relationship of power, knowledge, and identity. Thus, if power, knowledge and identity are constructed in classrooms, then they can be deconstructed and transformed in classrooms.

Street's work challenges researchers to reevaluate how our definitions of literacy and our underlying ideologies about literacy affect our research agendas. Several researchers have begun to rethink literacy studies in the way that Street suggests. Baynham (1995) offers, for example, an ideological definition of literacy as situated social practice that both shapes and is shaped by deeply held ideological positions in the larger society. Edelsky (1991) presents a careful "rethinking" of whole language as a critical pedagogy capable of challenging traditional definitions of literacy as ideologically and politically neutral. The New London Group (1996) suggests a pedagogy of multiliteracies to account for the rapidly changing world view students face in a post-modern world. Irvine (1996) proposes a framework for developing post-colonial curricula which are radically context-specific and use critical approaches to literacy to explore social and political relationships between a historically marginalized group within a dominant community. Thus, there are researchers attempting to transform literacy practices in schools in order to challenge autonomous models from whom we might all benefit.

Accomplishing the reform called for by Street demands a radical rethinking of the why, how, and so what of literacy research and pedagogy. Street's current book effectively articulates a progressive research agenda that is an essential read for researchers and educators in the field of literacy. 


\section{NOTE}

1. This section is not meant to be a comprehensive review of literature on ethnographic research in schools or classrooms. I mention these studies as examples of research that address issues called for by Street.

\section{REFERENCES}

Applebee, A. (1984), Contexts for leaning to write: Studies of secondary school instruction. Norwood. N]: Ablex.

Baynham, M. (1995). Literacy practices: Investigating literacy in social contexts. New York: Longman.

Bourdieu, P. (1983). The field of cultural production, or, the economic world revisited. Poetics, 12: $195-220$.

Coles, G. (in press). The problem with reading: Literacy conflicts. New York: Farrar, Strauss \& Giroux.

Duranti, A. (1986). The audience as co-author: An introduction. Text, 6(3): 239-247.

Duranti, A. \& Goodwin, C. (1992). Rethinking context; Language as an interactive phenomenon. Cambridge, UK: Cambridge University Press.

Durantj A. \& Ochs, E. (1986). Literacy instruction in a Samoan village. In B. Schieffelin \& P. Gilmore (Eds.) The acquisition of literacy: Ethnographic perspectives. New Jersey: Ablex.

Duranti, A., Ochs, E. \& Ta'ase, E. (in press). Change and tradition in literacy instruction in a Samoan American community. In B. McLaughlin, B. McLeod, \& S. Dalton (Eds.), Teaching for success: Reforming schools for children from culturally and linguistically diverse backgrounds.

Edelsky, C. (1991). With literacy and justice for all: Rethinking the social in language and education. New York: Falmer.

Emig, J. (1971). The composing processes of twelfh graders. Urbana, IL: National Council of Teachers of English.

Foucault. M. (1977). Discipline and punish: The birth of a prison (A. Sheridan, trans.). London: Allen Lane.

Garfinkel, H. (1972). Studies of the routine grounds of everyday activities. In D. Sudnow (Ed.), Studies in social interaction. New York: Free Press, pp. 1-30.

Goffman, E. (1981). Forms of talk. Philadelphia: University of Pennsylvania Press.

Goodman, K. (1986). What's whole in whole language? Portsmouth, NH: Heinemann. (1996). On reading. Portsmouth, $\mathrm{NH}$ : Heinemann.

Goodwin, M. (1990). He-said-she-said: Talk as social organization among black children. Indianapolis: Indiana University Press.

Graves, D. (1983). Writing: Teachers and children at work. Portsmouth, NH: Heinemann. . (1994). A fresh look at writing. Portsmouth, NH: Heinemann.

Green, J. \& Dixon, C. (1996, Apri1). Talking texts into being: A cross-sase analysis of the relationship of oral and written texts in grades 1 and 5. Paper presented at the annual meeting of the American Educational Research Association, New York, April.

Gutierrez, K. (1992). A comparison of instructional contexts in writing: Process classrooms with Latino children. Education and Urban Society, 24: 241252.

(1993). How talk, context, and script shape contexts for learning: A cross case comparison of journal sharing. Linguistics in Education, 5: 335-365.

Gutierrez, K. \& Larson, J. (1994). Language borders: Recitation as hegemonic discourse, International Joumal of Educational Reform, 3(1): 22-36.

Gutierrez, K., Rymes, B. \& Larson, J. (1995). Script, counterscript and underlife in the classroom: James Brown versus Brown y. The Board of Education. Harvard Educational Review, 65(3): 445 471 .

Gutierrez, K., Larson, J., Rymes, B. \& Stone, L. (1995). Constructing classrooms as communities of learners. Unpublished manuscript, University of California, Los Angeles. 
Hanks, W. (1990). Referential practice: Language and lived space among the Maya. Chicago: University of Chicago Press.

Heath, S.B. (1983). Ways with words: Language, life, and work in communities and classrooms. Cambridge: Cambridge University Press.

Irvine, P. (1996). Forty miles and four hundred years: Toward a post-colonial curriculum for Native American students. Unpublished manuscript, University of Rochester, Rochester, New York.

Langer, J. \& Applebee, A. (1987). How writing shapes thinking. Urbana, IL: National Council of Teachers of English.

Larson, J. (1995a). Talk matters: The role of pivot in the distribution of literacy knowledge among novice writers. Linguistics and Education, 7(4): 277-302.

(1995b). Community construction of text: The value of talk among novice writers. Paper presented at the annual conference of the National Council of Teachers of English, San Diego, California, November.

(1996). The social construction of literacy in a kindergarten classroom. Paper presented at the World Conference on Literacy, Philadelphia, Pennsylvania, March.

. (in press). Indexing instruction: The social construction of the participation framework in kindergarten journal writing activity. Discourse and Society, $8(4)$

Luke, A. (1994). The social construction of literacy in the primary school. Melbourne, Australia: Macmillan.

New London Group (1996). A pedagogy of multiliteracies: Designing social futures. Harvard Educational Review, 66(1): 60-92.

Nystrand, M. (1989). A social-interactive model of writing. Written Communication, 6(1): 66-85.

Ochs, E. (1988). Culture and language development: Language socialization and language acquisition in a Samoan village. Cambridge: Cambridge University Press.

. (1992). Indexing gender. In A. Duranti \& C. Goodwin (Eds.), Rethinking context: Language as an interactive phenomenon. Cambridge, UK: Cambridge University Press, pp. 335-358..

Ochs, E. \& Taylor, C. (1992). Family narrative as political activity. Discourse and Society, 3(3): 301-340.

Ochs, E., Taylor, C., Rudolph, D. \& Smith, R. (1992). Storytelling as theory-building activity. Discourse Processes, 15: 37-72.

Perl, S. (1979). The composing processes of unskilled college writers. The Teaching of English, 13: 317-336.

Rogoff, B. (1990). Apprenticeship in thinking: Cognitive development in social context. New York: Oxford University Press.

Rymes, B. (1995). The construction of moral agency in the narratives of high school dropouts. Discourse and Society, 6(4): 495-516.

Schieffelin, B.B. \& Ochs, E. (1986). Language socialization across cultures. Cambridge: Cambridge University Press.

Street, B. (1995). Social literacies: Critical approaches to literacy in development, ethnography, and education. London: Longman. 